are equally effective checks against arbitrary or impetuous governmental action. A political democracy knows other than constitutional securities.

\title{
CONFLICT BETWEEN LOCAL AND NATIONAL INTERESTS IN ALIEN LANDHOLDING RESTRICTIONS
}

Early in 1948 the Supreme Court of the United States handed down its opinion in Oyama v. California, ${ }^{\mathrm{x}}$ the latest in a line of cases in which that court has considered state restrictions on alien landholding. Two concurring ${ }^{2}$ and two dissenting ${ }^{3}$ opinions make articulate a wide divergence in view as to the wisdom of condemning the California statute in whole or in part. By the terms of this alien land law a presumption is created that any conveyance to an eligible landholder is made with intent to avoid the statute if an ineligible alien pays the consideration for the conveyance. Oyama's minor citizen son was here the eligible landholder. Intent to avoid the statute by such a conveyance results in escheat to the state. Though the decision was specifically limited to declaring the statutory presumption unconstitutional, a dictum in a succeeding case ${ }^{4}$ indicates that a wider effect may be given to the holding than was at first apparent. If this is true, aliens may in the future again invoke the equal protection and due process guarantees of the Constitution, an approach unsuccessfully attempted in $1923^{5}$

In any event, the issue is at a critical stage which justifies a study of the historical origin of a theory sanctioning the exercise of an obviously discriminatory power by the states. For the decisions in these cases make clear a strong presumption of statutory validity, founded squarely on history and tradition. It has been contended that "the public policy of prohibiting the alien ownership of real property, except in very limited cases, has been an outstanding principle of the common law almost since its inception." 6 But the same principle of the common law is one completely at variance with the exercise by the states of

× 332 U.S. 633 ( 1948 ).

2 Justices Black and Murphy wrote concurring opinions. Justice Douglas joined Justice Black and Justice Rutledge joined Justice Murphy. The Black-Douglas opinion suggested that the California statute was inconsistent with federal powers over immigration and foreign affairs and denied to the alien the equal protection secured by the Fourteenth Amendment. Justices Murphy and Rutledge agreed that the law was based on racial prejudice and ought to be struck down under the Fourteenth Amendment.

3 The dissents by Justices Reed and Jackson, with Justice Burton joining the former, denied that the California presumption was unreasonable if, as the majority opinion pointed out, the policy of the California legislature was not to be questioned.

4 Note Justice Black's reference in Takahashi v. Game Commission, 334 U.S. 4Io, $42 \mathrm{I}$ (I948) to the cases cited in note 5 infra upholding the validity of the California and Washington alien land laws: "assuming the continued validity of such cases. ..."

5 Terrace v. Thompson, 263 U.S. I97 (I923); Porterfield v. Webb, 263 U.S. 225 (I923); Webb v. O'Brien, 263 U.S. 313 (I923); Frick v. Webb, 263 U.S. 326 (r923).

${ }^{6}$ This was the argument of the state in Terrace v. Thompson, 263 U.S. 197, 206 (I923). 
control over landholding by aliens. Restrictions on such landholding came into the common law in aid of the defense of England and as a product of her foreign policy. Since the United States government is constitutionally charged with the conduct of national defense and foreign affairs, both legal history and constitutional theory justify federal control of alien land laws.

It is hornbook learning that at common law an alien could not hald land. The restriction is often regarded as an inevitable part of the feudal system, by the very nature of which, it is said, landholding had to be restricted to citizens or subjects. ${ }^{7}$ But aliens, citizens, and subjects as we now know them did not exist in the early feudal period. Indeed, in England such distinctions would have been impossible. England was conquered by "aliens," one of them became king, and land was distributed to his followers. Under the circumstances such a thing as a common English nationality was for a long time inconceivable. It was not unusual for a man to hold land in France and England as a subject of both the French and English kings.

Common-law restrictions on alien landholding began in the thirteenth century with the crown's long struggle to maintain its claims to Normandy and other continental provinces. The English king in theory remained the Duke of Normandy, and allegiance from landholders there was due to him. The French, however, slowly occupied Normandy and compelled the lesser lords to obedience. ${ }^{8}$ It was considered by the English that the crown was being deprived of its rights to land in France, and in retaliation the English king seized the lands of Frenchmen and Normans in England. This established the "precedent." Efforts to retain the remaining possessions of the English crown in France led eventually to the Hundred Years' War, and during this time the common law developed the principle that aliens could not hold land.

Early in this period, it was not considered that the land seized had been permanently lost to the French or Norman tenant, and it was felt that he might well resume possession when peace came. ${ }^{9}$ Thus, some of the land seized was granted to new tenants with a proviso that it might be taken back when the

7 The explanation is generally that all land was held of the king and that to hold land of the king implied fealty to the sovereign. Fealty meant that one had to bear true faith and allegiance in opposition to all men. One born in a foreign country bore a natural allegiance to that country's sovereign from which he could not divest himself. Thus an alien could not bear fealty to the English king, since this would be in conflict with the alien's natural allegiance to the foreign king. The Laws Relating to Aliens, 3 Law. Mag. (n.s.) 264 (1845); Bailey, Rights and Duties of Aliens within National Boundaries, 55 Ky. L.J. I96, x99-200 (I927).

${ }^{8}$ Normandy was lost in the period $1189-1204$, but the loss was not accepted by the English king till r259. Tout, France and England 78 (I922).

9x Pollock and Maitland, History of English Law 460 (I899); Holdsworth, History of English Law 85 (1938); Selden Society, Select Cases Before the King's Council r 243-1482, xlvii-xlix, Ixxiii (I9I8). Some of the treaties signed in the intervals of peace specified that the lands be returned to the aliens. See Molyns v. Fiennes ( 1365 ), reprinted in Selden Society, Select Cases before the King's Council 49 (19I8), wherein on petition to King's Council such a treaty was carried into execution. 
Normans recognized the English king as their overlord. It is of this early time that Bracton speaks when he writes that "if a man living in obedience to the king of France claims land against you, you may except against him." Io This exception was considered a dilatory plea which served to bar an action only until peace was established and the king's rights were recognized in France. The French were the only aliens who had to be considered in this respect. There were other foreigners in England, but they were merchants who were without claims to or desires for English land.rr

But permanent peace never came, and in time Bracton's dilatory exception became peremptory. The plea that "you are the subject of a king who is at war with our king and you may not be answered here, for Englishmen are not answered in France" becomes simply "you are an alien." Thus it came to be the law that aliens could not hold land in England-not because of anything inherent in the feudal system ${ }^{12}$ but as an "exaggerated generalization" of the habit of seizing the lands of Frenchmen.13

Once the basic principle was established, the consequences were carefully worked out. Though an alien could not hold land, clearly he could take land by act of a person. ${ }^{\mathrm{I}}$ Thus a deed, gift, or devise gave the alien a title good against all the world except the crown..$^{55}$ Even as against the crown the alien held until,

ro Bracton, De Legibus Angliae $\$ 427 \mathrm{~b}$; see ibid., at $\$ \S 298,415 \mathrm{~b}, 428 \mathrm{~b}$.

Ix Pollock and Maitland, op. cit. supra note 9, at 462 .

${ }_{12}$ The usual argument that tenure meant that one could hold land under only one sovereign seems to be refuted by Bracton. Even in the event of war between two kingdoms in both of which a landowner holds land, the landowner could retain his land. He had to contribute personal service to the lord to whom he had sworn allegiance by homage, but he also had to insure the presence of forces due from him in respect to land held in the opposing kingdom. Bracton gives the names of some people who acted on this basis during the struggle for Normandy. Bracton, op. cit. supra note ro, at $427 \mathrm{~b}$. Thus Blackstone's statement that without restrictions on landholding by aliens "the design of introducing our feuds, the defense of the kingdom, would have been defeated," seems incorrect. 2 Bl. Comm. *249.

${ }_{13}$ "The truth seems to be that in the course of the thirteenth century our kings acquired a habit of seizing the lands of ... Frenchmen. . . . To us it seems that the king's claim to seize the lands of aliens is an exaggerated generalization of his claim to seize the lands of his French enemies." Pollock and Maitland, op. cit. supra note 9, at 462-63. Holdsworth, op. cit. supra note 9 , at 85 states, "Historically the rules of the common law as to the incapacity of the alien to own land inverts the order of cause and effect-it was because the king had seized the lands of these Normans that the common law arrived at its settled rules as to the ... incapacity of the alien to hold English land."

${ }^{2}$ Co. Litt. *2b; I Bl. Comm. *37x; I Bacon's Abridgment $x_{72}$ (7th ed., I832); Shepard's Touchstone * 56 ; Comyns, Digest of Laws of England 545 (5th ed., 1822); Kent, Comm. *55.

Is Anon., Goulds. 29 ( 1576 ) (alien purchased land and before an office found [note I6 infra] was convened the Queen made him a denizen. It was held that the land was not in escheat to the Queen before office found and that her confirmation of the alien's title was good); see Burk v. Brown, 2 Atk. 397, 398 (Ch., I742), where Lord Hardwicke said, "An alien, to be sure, is capable of taking by purchase; but by that is meant a conveyance at common law, or any other kind of purchase...." The American cases follow the common law where no statute interferes. McKinley Creek Mining Co. v. Alaska United Mine Co., 183 U.S. 563 (Igor); 
by an inquest of office found, ${ }^{16}$ he was divested of whatever right he had, and title was given the king. ${ }^{17}$ Until such time as an office was found against him the alien was entitled to all the rents and profits of the land. He had such right as to be able to suffer a common recovery and bar an entail. ${ }^{18}$ But he could not by deed pass a title which was good as against the crown, ${ }^{19}$ and on his death title to the property passed to the king without the necessity of an office found even if the alien had tried to devise the land to others..$^{20}$

Since he could not hold the land, the law would not aid him in taking. That is, though an alien might take by act of the parties, he could not take by act of law, for, it was said, the law would not frustrate itself by doing what would later have to be undone. Therefore, an alien could not take as an heir nor by dower or curtesy. ${ }^{2 x}$ If there were other heirs of equal degree who could take, the

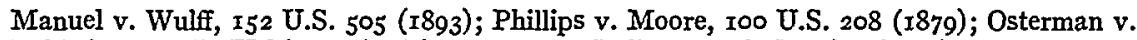
Baldwin, 6 Wall. (U.S.) II6 (I867); Cross v. DeValle, I Wall. (U.S.) 5 (I863).

${ }^{16}$ Blackstone describes office found as "an inquiry made by the king's officers . . or by writ to them sent for that purpose, or by commissioners specially appointed, concerning any matter that entitles the king to possession of lands or tenements, goods or chattels. This is done by a jury of no determinate number ... to inquire whether ... C, who has purchased lands, be an alien; which is another case of forfeiture. ..." 3 Bl. Comm. * ${ }_{258}$.

${ }_{17}$ Page's Case, 5 Co. $5^{2 a}$ ( 1588 ) (property was devised to one made a denizen before the death of the testator. The letters of denization were mistakenly dated after testator's death. Upon an office found against the devisee, an alien born, it was held that a commission for an inquest of office found to entitle the crown to the estate and possession of the lands must be under the Great Seal. Since this commission was under the Exchequer Seal, it was void as against the devisee); Duplessis v. Attorney General, I Brown P.C. 4I5 (H.L., 1753) (the crown may invoke the aid of equity to discover the fact of alienage under an inquest of office found, for an alien holds real interests only for the benefit of the crown; but the latter can only recover the land by a commission under the Great Seal, and to prove the facts is entitled to the assistance of a court of equity). For the same case in the Court of Exchequer see Attorney General v. Duplessis, 2 Ves. Sr. 286 (Exch., r75I); see also Attorney General v. Weeden \& Shales, I Park 267 (1699) (inquest of office found is necessary to recover the chose in action of an alien enemy). The United States Supreme Court follows similar rules. Fairfax's Devisee v. Hunter's Lessee, 7 Cranch (U.S.) 602 (I8r3); Society for the Propagation of the Gospel in Foreign Parts v. New Haven and W. Weaver, 8 Wheat. (U.S.) 464 (1823).

${ }^{8} 8$ Anon., Goulds. $x_{2}$ ( $x_{5} 88$ ) (an alien born purchased land in tail with a remainder to a stranger in fee. The alien suffered a common recovery to his own use in fee and later an office was found against him. It was held that the Queen had a fee simple and that the remainder to the stranger was gone).

19 Fish v. Klien, 2 Mer. 43 I (Ch., I8I7); Co. Litt. *42b: "But many that have capacity to take, are disabled to enfoeffe as ... aliens borne"; see Radcliffe v. Roper, 10 Mod. 89 (Ch., I7I2).

${ }^{20}$ Co. Litt. *2b; I Bacon's Abridgment I73-74 (7th ed., I832): "If an alien purchase land and die, then the freehold is in the king without office found, because no man can take it as heir to an alien, therefore the freehold is cast upon the king. ..."; 2 Bl. Comm. *249: "And as they [aliens] can neither hold by purchase nor by inheritance, it is almost superfluous to say that they can have no heirs, since they can have nothing for an heir to inherit; but so it is expressly holden because they have not in them any inheritable blood." This view was accepted in Blight's Lessee v. Rochester, 7 Wheat. (U.S.) 534 (I822).

${ }^{2 x}$ Collingwood v. Pace, I Keb. 65 (C.P., I66I), and see opinion of Bridgman, C.J., in Bridg. 4IO (I66I); Thomas v. Acklam, 2 Barn. \& Cress. 779 (K.B., I824); see Rittson v. 
alien would simply be ignored. For a long time it was held that an inheritance could not be traced through an alien. The extremes to which the concept was pushed is illustrated by a holding that one of two brothers, native-born Englishmen of an alien father, could not be the heir of the other, for descent would have to be traced through the father who had no "inheritable blood." ${ }_{22}$ This opinion seems later to have been overruled by the courts, ${ }^{23}$ though some uncertainty remained until the law was later clarified by statute. ${ }^{24}$

Equity followed the law, ${ }^{25}$ although doctrines peculiar to equity could make some differences in the results which might occur in a particular case. Thus, the doctrine of equitable conversion would turn "land into money" in a situation where real estate was left in trust to be sold and the proceeds delivered over to an alien legatee. ${ }^{26}$

To these rather rigid rules only one exception was recognized. For purposes of trade, friendly alien merchants were allowed to hold the lease of a house. ${ }^{27}$ Though this exception was later broadened to include all aliens, ${ }^{28}$ on the whole the rules against alien landholding remained until 1870 . In that year a statute abolished the disability, and aliens were granted the same rights as English subjects to hold, transfer, and inherit land. ${ }^{29}$

Problems involving the landholding disability of aliens arose almost im-

Stordy, 3 Small \& Giff. 230 (Ch., 1855). The point was apparently argued but not decided in Boistard v. Cumbwell (1243), reprinted in Selden Society, Select Cases before the King's Council I 243-I382, at I (Igr8). The American cases are Mager v. Grima, 8 How. (U.S.) 490 (I850); Levy v. McCartee, 6 Pet. (U.S.) 102 (I832); Inglis v. Sailor's Snug Harbour, 3 Pet. (U.S.) 99 (I830); Orr v. Hodgson, 4 Wheat. (U.S.) 453 (18I9); Dawson's Lessee v. Godfrey, 4 Cranch (U.S.) $32 \mathrm{I}$ (1808).

${ }_{2} 2$ Bl. Comm. *250; Co. Litt. *8a.

${ }^{23}$ Collingwood v. Pace, I Vent. 4ra (Ex. Ch., I664); for Bridgman's dissent see Bridg. 4I4 (1664).

24 II \& I2 W. III, c. 6 (1700); 25 Geo. III, c. 39 (I75I).

${ }_{25}$ Sharp v. St. Saveur, 7 Ch. App. 343 (I871); Barrow v. Wadkin, 24 Beav. I (Ch., 1857 ); Rittson v. Stordy, 3 Small \& Giff. 230 (Ch., I855); Fourdin v. Goudey, 3 My. \& Keene 383 (Ch., I834); Fish v. Klien, 2 Mer. 43I (Ch., I8I7); Burk v. Brown, 2 Atk. 397 (Ch., 1742); Rex v. Holland, Alleyn I4 (Ch., I68I).

${ }^{26}$ Craig v. Leslie, 3 Wheat. (U.S.) 563 (r8r8); Du Hourmelin v. Sheldon, 4 My. \& Cr. 525 (Ch., r839).

${ }_{27}$ " . . . . as to a lease for years there is a diversity between a lease for years of a house for the habitation of a merchant stranger being an alien, whose king is in league with ours, and a lease for years of lands. ... For if he takes a lease for years ... [of the latter] upon office found the king shall have it. But of a house for habitation he may take a lease for years as incident to commerce, for without habitation he cannot merchandize or trade. . . . But if the alien be no merchant, then the king shall have the lease for years albeit it were for habitation...." Co. Litt. *2b; Pollock and Maitland, op. cit. supra note 9 , at 464-65.

${ }^{28}$ The alien in legal history, 163 L.T. 497,498 col. 2 (1927); The Laws Relating to Aliens, op. cit. supra note 7 , at 264 (1845).

${ }^{29} 33$ \& 34 Vict., c. I4 (1870); see The Land Law of Great Britain with Especial Reference to the Rights of Aliens, I8 Am. L. Reg. (n.s.) 465 (I879). 
mediately when the United States became an independent nation. Many colonial landholders adhered to the British crown. As a result, many of the states passed laws declaring their lands forfeited to the state on the basis of the alienage of such persons. ${ }^{30}$ The "Tories" argued against such statutes on the ground that British subjects born in the colonies before July 4, I 776 should not be considered aliens. ${ }^{3 x}$ However, it was later settled that citizenship at the time the land descended, and not at birth, was controlling. ${ }^{32}$ When cases arising out of the state forfeiture laws reached the Supreme Court, it accepted the common-law view of the landholding disability of aliens. ${ }^{33}$ From this point of view the Court has never departed, ${ }^{34}$ and today, unless modified by statute ${ }^{35}$ or treaty, ${ }^{36}$ alien landholding in the United States rests on the same basis as it did in England at the time of the American Revolution.

Statutes defining the ability of the alien to hold land have been enacted by the federal government. ${ }^{37}$ Under these laws, aliens who are bona fide residents of the United States, or who have declared their intention to become American citizens, or whose right to hold land is secured by a treaty have landholding rights equivalent to those of citizens of the United States. These statutes are, however, restricted in their application to the Territories of the United States and to the District of Columbia..$^{8}$ But the statutes make it clear that Congress

${ }^{30}$ Examples are the Maryland statute involved in Smith v. Maryland, 6 Cranch (U.S.) 286 (x8xo); the Virginia statute in Fairfax's Devisee v. Hunter's Lessee, 7 Cranch (U.S.) 602 (1813); the New York statute in Harden v. Fisher, I Wheat. (U.S.) 300 (I8I6).

${ }^{35}$ McIlvaine v. Coxe, 2 Cranch (U.S.) 280 (I805); Lambert v. Paine, 3 Cranch (U.S.) 97 (I805). The argument was based on Calvin's Case, 7 Co. Rep. I (Ex. Ch., I608), where it was held that a Scotchman born after the Scotch king had become the English king was not an alien, for he was born within the ligeance of the English king. Here it was argued that Englishmen and citizens of the United States were born within the same allegiance and thus could not be aliens in each other's countries.

${ }^{32}$ Dawson's Lessee v. Godfrey, 4 Cranch (U.S.) 320 (I808).

33 Fairfax's Devisee v. Hunter's Lessee, y Cranch (U.S.) 602 (1813).

34 McKinley Creek Mining Co. v. Alaska United Mining Co., I83 U.S. 563 (IgoI); Manuel v. Wulff, 152 U.S. 505 (1894); Phillips v. Moore, 100 U.S. 208 (1879); Osterman v. Baldwin, 6 Wall. (U.S.) Ix6 (1867); Cross v. DeValle, x Wall. (U.S.) 5 (I863); Mager v. Grima, 8 How. (U.S.) 490 (I850); Shanks v. Dupont, 3 Pet. (U.S.) 242 (1830); Inglis v. Sailor's Snug Harbour, 3 Pet. (U.S.) 99 (1830); Governeur's Heirs v. Robertson, II Wheat. (U.S.) 333 (1826); Blight's Lessee v. Rochester, 7 Wheat. (U.S.) 534 (1822); Craig v. Radford, 3 Wheat. 594 (I818).

35 Bly the v. Hinckley, I80 U.S. 333 (IgOI); Griffith v. Godey, II3 U.S. 89 (1884); Sullivan v. Burnett, I05 U.S. 334 (188I); Beard v. Rowan, 9 Pet. (U.S.) 30I (I835); Spratt v. Spratt, I Pet. (U.S.) 343 (r828).

${ }^{36}$ Jordan v. Tashiro, 278 U.S. I23 (I928); Geoffrey v. Riggs, I33 U.S. 258 (I889); Hauenstein v. Lynham, 100 U.S. 483 (I879); Carneal v. Banks, to Wheat. (U.S.) I82 (I825); Jackson v. Clarke, 3 Wheat. (U.S.) I (I8I8); Chirac v. Chirac, 2 Wheat. (U.S.) 259 (I8I7); Harden v. Fisher, I Wheat. (U.S.) 300 ( $x 816$ ). (I942).

${ }^{37} 29$ Stat. 618 (1897), 8 U.S.C.A. $\$ \S 7$ I, 72 (1942); 33 Stat. 733 (r9o5), 8 U.S.C.A. $\$ 78$

${ }^{38}$ Alien landholding in Hawaii is governed by separate and more rigorous provisions. 42 Stat. II7 (I92x), 8 U.S.C.A. $\$ \S 83-86$ (I942). 
has not established, by enunciating a standard as to who may become a citizen, a national policy to determine who may hold land. Thus it can hardly be argued that state laws further any federal policy by basing the ability of an alien to hold land on his eligibility to citizenship under the naturalization laws.

Traditionally, questions of title, ownership, and inheritance of land are areas in which the several states take a dominant interest. ${ }^{39}$ But the federal government can regulate the terms and conditions under which aliens may live within the states..$^{\circ}$ From the beginning of its foreign affairs the federal government has sought to handle the alien landholding question by treaty, ${ }^{45}$ and today no federal statute exists which applies in terms to alien landholding within the states. Had such a statute been passed it could be argued that the federal government had occupied the field and that, thereafter, no state legislature could act in regard to alien landholding. ${ }^{42}$

The common-law rules as to alien ownership of land were developed, or at least justified, on ground of national defense. Lord Coke considered that these restrictions were intended to prevent a fifth column "as was excellently shadowed by the Trojan horse. ..." 43 With this policy argument other eminent justices agree. 44 Blackstone, who based his argument for these restrictions on national defense, also suggested that tenurial notions were involved. 45 But the tenure explanation seems, in the light of later learning, clearly incorrect. It was not feudal tenurial notions but French enmity which first moved the English king to act. Expressed in modern terminology: Foreign policy and the power to make war, not land law, are the sources from which these alien restrictions arise.

39 Blythe v. Hinckley, x80 U.S. 333 (Igor); Beard v. Rowan, 9 Pet. (U.S.) 301 (1835); see also Jones v. Jones, 234 U.S. 615 (1914); Clarke v. Clarke, I 78 U.S. I86 (I900); De Vaughn v. Hutchinson, I6 5 U.S. 566 (1897); United States v. Crosby, 7 Cranch (U.S.) II 5 (I8I2).

${ }^{40}$ Hines v. Davidowitz, $3^{12}$ U.S. 52 (I940); Henderson v. Mayor of New York, 92 U.S. 259 (1875); Chy Lung v. Freeman, 92 U.S. 275 (1875); Arrowsmith v. Vorhies, 55 F. 2d 310 (D.C. Mich., 1931); Ex parte Cue, Ior Cal. 197, 35 Pac. 556 (1894).

4ะ The treaty with France of Feb. 6 , I778 provided (Art. I3) that the subjects and inhabitants of the United States "may by Testament . . . or otherwise dispose of their Goods moveable or immoveable in favour of such persons as to them shall seem good; and their Heirs, Subjects of the Said United States residing whether in France or elsewhere may succeed them $a b$ intestat. ... [and] The Subjects [of the French King] shall enjoy ... an entire and perfect Reciprosity...." 2 Miller, Treaties and Other International Acts of the United States II, (193I); see also article 6 of the treaty with the Netherlands of October 8, 1782, ibid., at 65, (I93); articles 5 and 6 of the Preliminary Treaty of Peace with Great Britain of Nov. 30, I 782 , ibid., at 98,99 (I93I).

${ }^{2}$ Hines v. Davidowitz, 3 I2 U.S. 52, 68 n. 23 (1940).

${ }_{43}$ Calvin's Case, 7 Co. Rep. Ia, I8b (Ex. Ch., I608). Lord Coke also mentions that there might be a failure of justice, for aliens might get a great part of the land in the realm, and since aliens born "cannot be returned of juries" there would be no one to try issues of fact in the king's courts.

44 Egerton (Lord Ellesmere), The Speech of the Lord Chancellor of England, in Exchequer Chamber, touching the Post-Nati 86, 87 (I609); Bridgman, C. J., in Collingwood v. Pace, Bridg. 4I5, 43I (Ex. Ch., I664).

452 Bl. Comm. *249. 
Our treatment of foreign nationals is an important and delicate aspect of international affairs. Discrimination, actual or imagined, has in the past led to grave international controversy and even to war..$^{46}$ In these circumstances to talk of alien landholding as a topic of interest primarily to the states is to ignore reality. In the event of war or a demand for indemnity "would California alone suffer, or all the Union?" 47 Clearly, "legal imposition of [restrictions] upon aliens . . . bears an inseparable relationship to the welfare and tranquillity of all the states, and not merely to the welfare and tranquillity of one." ${ }_{48}$

Failure to recognize this, and the consequent use of the power by the states rather than the federal government, have at times been most harmful to the relations of the United States with other nations. This can be made clear by a view of the circumstances under which the Califormia statute was passed and the effects of the enactment. The act was passed only after years of intense racial agitation sparked primarily by local politicians, labor groups, and farmers. Presidents Roosevelt and Taft and Secretary of State Bryan successively intervened in I907, I9II, and IgI3 to prevent passage of the bill. In IgI3 federal intervention failed and the bill became law. Passage of the law, and the propaganda which preceded it, led to great outbursts of anti-American feeling in Japan and the organization of numerous anti-American societies. Several times Japanese reaction to California policy pushed that country close to war with the United States, and there is little doubt that the discrimination embodied in the California act was used by Japanese propagandists to unify their own people and the people of Asia behind a policy of Japanese expansion.49

Traditionally, restrictions on the rights of aliens to hold land have been regarded as an aspect of land law and, therefore, of peculiar concern to the states. This view, it is suggested, overlooks both the lessons of history and the need for national unity in foreign affairs. The traditional position makes possible arguments about "unique economic considerations in this state" and less respectable polemics, motivated by selfishness or racial hysteria, devoted to the consequence of foreigners holding land. The logic of this position can accommodate the absurdity of permitting landholding by an eligible alien, who is non-resident and devoid of any intention of becoming a citizen or resident; yet an alien ineligible for citizenship may not hold land even though bound by residence, family, and means of livelihood to the United States.

Tradition and history leave much unanswered in the field of alien rights. Questions of civil and economic liberty are involved. But a national defense rationale is at least consistent with the history of the common law and seems

${ }^{46}$ Dunn, The Protection of Nationals (1932).

47 Chy Lung v. Freeman, 92 U.S. 275, 279 (1875); see also cases cited note 40 supra.

${ }_{48}^{8}$ Hines v. Davidowitz, 312 U.S. 52, 65-66 (1940).

$49 \mathrm{~A}$ brief history of the California statute may be found in Justice Murphy's concurring opinion in Oyama v. California, 332 U.S. 63I (r948); see also McWilliams, Prejudice I4-7I (1946); Konvitz, The Alien and the Asiatic in American Law, c. 5 (1946). 
constitutionally sound. It assures to the federal government a necessary power less likely to be subject to the abuses which have characterized California's efforts in this area. If discriminatory statutes are necessary, let them be based on considerations of national welfare and not on the racism and narrow economic or political considerations which have motivated state action denying special classes of aliens the right to hold land.

\section{COMMON-LAW REGULATION OF THE IDEA MARKET}

The tremendous commercial value of ideas today is perhaps nowhere so apparent as in the motion picture, radio, and advertising industries. ${ }^{x}$ An "idea" that a musical comedy should have its scene set at Mackinac Island instead of Hawaii may be sufficient to cause the investment of hundreds of thousands of dollars and to make possible a gross profit in the millions. An "idea" that it would be desirable to abbreviate an advertising slogan for a popular-brand cigarette may result in a few cryptic letters being printed in countless issues of newspapers and magazines and being drummed into the ears of innumerable cigarette consumers via radio. Someone's suggestion that it would be a good idea to broadcast a disc jockey on a nation-wide radio hookup has consequences that are measurable in large sums. While the bulk of these ideas is probably originated within the studios and professional agencies, ${ }^{2}$ a number are developed independently by professional free-lance writers and casual amateurs. These in turn are submitted to the industry in the abbreviated form of sketches and outlines. The extraordinary value which is placed upon minor variants of an idea and the striking similarity between such variants create complex problems in the marketing of ideas. These problems arise both from the possibility of literary piracy on the one hand and from the danger of spurious claims on the other.

The copyright laws do not solve the problem, since their protection is confined to authors whose material has been published, ${ }^{3}$ while controversy in these cases springs from charges that unpublished material has been pirated. But the common law has long recognized an author's property right to his creation even before publication. ${ }^{4}$ This protection is independent of ${ }^{5}$ and unaffected by 1947).

${ }^{x}$ See Johnston v. Twentieth Century-Fox Film Corp., 187 P. 2d 474, $47^{8}$ (Cal. App.,

= The experience of radio station WGN, Chicago, seems to be typical of the entire field. With rare exceptions, unsolicited ideas have been independently developed by professionals working for the station.

3 "The statutory right is of no value, unless there is a publication. . . "Brandeis and Warren, The Right to Privacy, 4 Harv. L. Rev. I93, 200 (1890).

4 See Caliga v. Inter-Ocean Newspaper Co., 2I5 U.S. I82, I88 (Igog); Bobbs-Merrill Co. v. Straus, 210 U.S. 339, 346 (1908); Wheaton v. Peters, 8 Pet. (U.S.) 591, 657 (1834); Frohman v. Ferris 238 Ml. 430, 435 (rgog), aff'd 223 U.S. 424 (rgI2). Cf. Cal. Civ. Code (Deering, I94I) $\$ 8980,983$.

5 See Paige v. Banks, I3 Wall. (U.S.) 608, 6r4 (1871); Little v. Hall, I8 How. (U.S.) 165, 170 (1855). 